\title{
PENGARUH MUTU INTENSIFIKASI TERHADAP PRODUKSI PADA USAHATANI KELAPA SAWIT (Elaeis guenensis, Jacq) DI KECAMATAN SUNGAI RAYA KABUPATEN ACEH TIMUR
}

\author{
Ir. HANISAH, MP ${ }^{1}$ / Juliana ${ }^{2}$ \\ 1Dosen Tetap Program Studi Agribisnis Fakultas Pertanian \\ 2Mahasiswa Program Studi Agribisnis \\ Universitas Samudra, Kota Langsa-Aceh
}

\section{ABSTRAK}

Permasalahan dalam penelitian ini adalah apakah faktor mutu intensifikasi yaitu : pemupukan, pemberantasan hama/penyakit dan pemanenan mempengaruhi produksi pada usahatani kelapa sawit di Kecamatan Sungai Raya Kabupaten Aceh Timur. Tujuan penelitian ini adalah untuk mengetahui pengaruh mutu intensifikasi yaitu : pemupukan, pemberantasan hama/penyakit dan pemanenan terhadap produksi pada usahatani kelapa sawit di Kecamatan Sungai Raya Kabupaten Aceh Timur. Penelitian ini menggunakan "metode survei". Objek penelitian ini adalah petani yang menanam tanaman kelapa sawit di Kecamatan Sungai Raya Kabupaten Aceh Timur. Ruang lingkup penelitian ini terbatas pada pengaruh mutu intensifikasi terhadap produksi usahatani kelapa sawit di daerah penelitian. Waktu penelitian ini dilaksanakan pada Bulan Januari sampai dengan Maret 2015. Hasil penelitian rata-rata umur petani kelapa sawit di daerah penelitian adalah 42,59 tahun, dengan masa pendidikan 10,41 tahun, pengalaman berusahatani 12,59 tahun dan besarnya tanggungan keluarga rata-rata 4 orang, sedangkan rata-rata luas garapan petani kelapa sawit di daerah penelitian adalah 2,10 Ha. Rata-rata skor mutu pemupukan pada usahatani kelapa sawit di daerah penelitian adalah 2,66 skor, rata-rata skor mutu pengendalian hama/penyakit 2,58 skor dan ratarata skor mutu pemanenan 2,78 skor, rata-rata skor mutu pemupukan, mutu pengendalian hama/penyakit dan mutu pemanenan menunjukkan nilai skor yang sangat tinggi. Rata-rata produksi pada usahatani kelapa sawit Desa Buket Drien 18.540,98 kg/tahun, Desa Alue Rangan 17.997,65 kg/tahun dan Desa Gajah Meuntah 18.664,35 Kg/tahun. Rata-rata produksi pada usahatani kelapa sawit di daerah penelitian $18.380,41 \mathrm{Kg} / \mathrm{UT} /$ tahun atau $8.752,58 \mathrm{Kg} / \mathrm{Ha}$ /tahun. Hasil regresi linear berganda diperoleh persamaan : $Y=5,935+0,507 \quad X_{1}+0,489 \quad X_{2}+0,073 X_{3}$. Hasil perhitungan koefisien determinasi menunjukkan bahwa besarnya $R^{2}=0,887$. Ini berarti variasi terhadap naik turunnya produksi ( $Y$ ) dipengaruhi oleh mutu pemupukan $\left(\mathrm{X}_{1}\right)$, mutu pengendalian hama/penyakit $\left(\mathrm{X}_{2}\right)$ dan mutu pemanenan $\left(\mathrm{X}_{3}\right)$ sebesar $88,7 \%$ dan sisanya $11,3 \%$ lagi dipengaruhi oleh faktor lain yang tidak ikut diteliti dalam penelitian ini. Hasil pengujian secara serempak dapat dilihat bahwa $\mathrm{F}$ cari $=78,50>\mathrm{F}$ tabel pada tingkat kepercayaan $95 \%=2,92$ dan 99\%=4,51, sehingga mutu pemupukan, mutu pengendalian hama/penyakit dan mutu pemanenan secara serempak berpengaruh sangat nyata terhadap produksi. Hasil pengujian secara parsial mutu pemupukan dapat dilihat bahwa $t_{1}$ cari $=6,1084>$ t tabel pada tingkat kepercayaan $95 \%=1,6973$ dan $99 \%=2,4573$ sehingga mutu pemupukan secara parsial berpengaruh sangat nyata terhadap produksi. Hasil pengujian secara parsial mutu pengendalian hama/penyakit dapat dilihat bahwa $t_{2}$ cari $=5,9634>t$ tabel 95\%=1,6973 dan 99\%=2,4573, sehingga mutu pengendalian hama/penyakit secara parsial berpengaruh sangat nyata terhadap produksi. Hasil pengujian secara parsial untuk mutu pemanenan dapat dilihat bahwa $t_{3}$ cari $=1,0282<t$ tabel pada tingkat kepercayaan 95\%=1,6973 dan 99\%=2,4573, sehingga mutu pemanenan secara parsial tidak perpengaruh terhadap produksi.

(Kata kunci : mutu intensifikasi, produksi).

Kata Kunci: Mutu, Pemupukan, Hama, Penyakit, Pemanenan, Produksi

\section{A. PENDAHULUAN}

Saat ini usahatani yang bersifat agribisnis telah banyak diusahakan masyarakat pada usaha tanaman perkebunan. Salah satu jenis tanaman perkebunan yang diusahakan oleh petani saat ini adalah kelapa sawit (Elaeis guinensis, Jacq). Kelapa sawit merupakan komoditas tanaman perkebunan yang diusahakan oleh petani dengan tujuan untuk memperoleh produksi yang maksimal.

Indonesia adalah penghasil minyak kelapa sawit di dunia, untuk meningkatkan produksi kelapa sawit dilakukan kegiatan perluasan areal pertanaman (ekstensifikasi), meningkatkan AGRISAMUDRA, Jurnal Penelitian Vol.2 No. I Januari-Juni 2015 produksi kelapa sawit tanpa memperluas ateal tanam (intensifikasi) dan meningkatkan produksi kelapa sawit dengan perbaikan sarana/prasarana (rehabilitasi). Pelaku usahatani kelapa sawit di Indonesia terdiri dari perusahaan perkebunan besar swasta, perkebunan negara dan perkebunan rakyat. Usaha perkebunan kelapa sawit rakyat umumnya dikelola dengan model kemitraan dengan perusahaan besar swasta dan perkebunan negara. Khusus untuk usahatani kelapa sawit rakyat, permasalahan umum yang dihadapi antara lain rendahnya produktivitas dan mutu produksinya. 
Menurut Sugito (1993:1), Kelapa sawit bukan tanaman asli Indonesia, namun kenyataannya mampu hadir dan berkiprah di Indonesia tumbuh dan berkembang dengan baik (perkebunannya dapat ditemukan antara lain di Sumatera Utara dan Aceh dan produk olahannya minyak sawit menjadi salah satu komoditas perkebunan yang handal.

Bagian tanaman kelapa sawit yang dapat dimanfaatkan dan bernilai ekonomi tinggi adalah buahnya yang tersusun dalam sebuah tandan yang biasanya disebut dengan Tandan Buah Segar (TBS). Buah sawit di bagian sabut (mesocarp) menghasilkan minyak sawit kasar atau CPO (Crude Palm Oil) sebanyak 20 - 24 \% sedangkan bagian inti dari buah kelapa sawit menghasilkan minyak inti sawit atau PKO (Palm Kernel Oil).

Minyak sawit dan minyak inti sawit umumnya digunakan untuk pangan dan non pangan. Dari segi pangan, minyak kelapa sawit atau inti minyak inti sawit digunakan sebagai bahan untuk membuat minyak goreng, lemak pangan, margarine, lemak khusus (substitusi cacao butter), kue, biskuit atau es krim. Produk pangan ini umumnya melalui proses fraksinasi, rafinasi dan hidrogenasi (Rismawan, 2010:4).

Prospek pasar dunia untuk minyak kelapa sawit dan produknya cukup baik untuk itu pengembangan usahatani kelapa sawit sebagai tanaman tahunan terus dikembangkan baik dari pihak negara, swasta maupun rakyat setempat. Kelapa sawit sebagai tanaman tahunan perkebunan andalan di Indonesia terus diperhatikan oleh pemerintah, baik dari segi perluasan areal maupun paket teknologi budidaya dengan tujuan untuk meningkatkan produksi kelapa sawit yang dihasilkan.

Tanaman kelapa sawit menyebar luas di seluruh Indonesia, dengan produktivitas yang relatif rendah. Hal ini disebabkan karena benih yang digunakan tidak memenuhi persyaratan yaitu menggunakan benih palsu, gangguan hama dan penyakit, teknik bercocok tanam yang belum tepat, penggunaan pupuk yang tidak berimbang, penunasan yang terlambat, sistim pengolahan tanah dan perlakuan pasca panen yang belum tepat.

Ditinjau dari berbagai aspek Kabupaten Aceh Timur sangat potensial untuk pengembangan tanaman kelapa sawit, baik ditinjau dari segi keadaan tanah, iklim, luas lahan dan penyediaan tenaga kerja maupun keadaan sosial ekonomi petani di daerah tersebut.

Kecamatan Sungai Raya merupakan salah satu kecamatan di Kabupaten Aceh Timur yang juga memiliki potensi yang sangat tinggi untuk pengembangan tanaman kelapa sawit dengan sistem intensifikasi. Sistem intensifikasi tanaman kelapa sawit merupakan cara yang sangat tepat dalam peningkatan produksi karena peningkatan produksi kelapa sawit tanpa memperluas areal tanam.

Intensifikasi pertanian adalah sistem pembudidayaan tanaman atau hewan yang menggunakan masukan (seperti tenaga kerja dan modal) dalam ukuran besar relatif terhadap luas lahan. Hal ini dilakukan karena pertimbangan efisiensi lahan untuk meraih keuntungan yang besar.

Masukan besar diperlukan untuk aplikasi berbagai teknologi pertanian, seperti penggunaan pupuk, penggunaan pestisida untuk pemberantasan hama/penyakit dan pemanenan yang benar. Selain itu irigasi juga dilakukan secara terkendali sehingga memerlukan investasi yang besar.

Hasil usahatani dengan pertanian intensif biasanya sangat tinggi karena didukung oleh teknologi yang didasarkan pada berbagai riset terlebih dahulu. Pertanian industrial atau pertanian yang menghasilkan bahan baku industri biasanya akan menerapkan semua teknologi yang tersedia sehingga produksi memberikan 
keuntungan yang besar dan memenuhi target kuantitas dan standar kualitas.

Suatu usahatani termasuk tanaman kelapa sawit dapat menerapkan sebagian atau seluruh teknologi tinggi yang tersedia untuk melaksanakan pertanian intensif. Sebagai contoh teknologi yang dipakai untuk meningkatkan produksi kelapa sawit di sejumlah daerah termasuk Kecamatan Sungai Raya memiliki sejumlah karakteristik pertanian intensif, tetapi tidak semuanya digunakan.

Karakteristik sistem intensif tanaman kelapa sawit dilakukan dengan cara pengolahan lahan yang benar, pemilihan benih unggul, pengairan yang baik, pemupukan yang berimbang, pemberantasan hama/penyakit, panen dan pengolahan pasca panen dan pemasaran. Kegiatan intensifikasi tersebut dikenal dengan panca dan sapta usahatani.

Dalam penelitian ini dianalisis pengaruh mutu intensifikasi usahatani kelapa sawit yang meliputi pemupukan, pemberantasan hama/penyakit dan pemanenan terhadap produksi sedangkan faktor lain dianggap tetap (cateris paribus)

\section{B. TUJUAN PENELITIAN}

Adapun tujuan dari penelitian ini adalah untuk mengetahui pengaruh mutu intensifikasi yaitu : pemupukan, pemberantasan hama/penyakit dan pemanenan terhadap produksi pada usahatani kelapa sawit di Kecamatan Sungai Raya Kabupaten Aceh Timur.

\section{TINJAUAN TEORI}

Intensifikasi pertanian adalah salah satu usaha untuk meningkatkan hasil pertanian dengan cara mengoptimalkan lahan pertanian yang sudah ada. Intensifikasi pertanian memang sangat dianjurkan terutama daerah-daerah yang sempit lahan garapannya agar produk pertanian bisa lebih banyak dengan kualitas yang lebih baik pula. Mengoptimalkan lahan pertanian yang AGKISA/VIUUKA, Jurnal renelıtıan vol. L INo. I Januarı - Juni 2015 sudah ada, bisa dilakukan dengan beberapa cara. Su'ud (1996:62) menyatakan bahwa: "Intensifikasi dimaksudkan penambahan modal dan tenaga kerja pada kesatuan luas tanah yang telah ada dengan memperbaiki cara pengolahannya dalam meningkatkan hasil pertanian".

Darianto (2007 : 32) menyatakan bahwa : Kegiatan intensifikasi pertanian adalah : Pemberian pupuk sesuai aturan. Pupuk sangat diperlukan walau sebenarnya dalam tanah sendiri sudah terkandung banyak zat yang dibutuhkan oleh tanaman. Pilihlah pupuk dengan tepat, apakah harus memakai pupuk alami (misal: kompos) atau pupuk buatan (misal: NPK). Tak hanya jenis pupuk, tapi cara, dosis dan waktu pemberian pupuk pun harus diperhatikan agar intensifikasi pertanian bisa sukses menghasilkan produk yang berkualitas. Pemberantasan hama/penyakit pengganggu tanaman yang bisa menurunkan kualitas maupun kuantitas produk pertanian.

Pemupukkan merupakan suatu kegiatan yang penting dalam intensifikasi pertanian termasuk pada usahatani kelapa sawit. Dengan pemupukkan yang benar maka tersedianya unsur hara dapat terpenuhi, sehingga tanaman tidak kekurangan unsur hara tersedia di dalam tanah.

Selanjutnya Wayan Artha (2008 : 35) menjelaskan bahwa : Intensifikasi pertanian adalah usaha untuk meningkatkan produksi pertanian dengan tidak menambah luas lahan dan melalui langkah dasa usaha tani, antara lain:

a. Pengolahan tanah dengan dicangkul, dibajak, atau ditraktor sehingga tanah menjadi gembur. Melalui pengolahan tanah seperti ini, diharapkan terjadi sirkulasi udara tanah dan unsur hara siap diserap akar tanaman. 
b. Penggunaan bibit unggul yang tahan terhadap penyakit dan hasilnya berlipat ganda.

c. Pengairan secara teratur yang airnya berasal dari waduk atau bendungan.

d. Penggunaan pupuk yang berupa pupuk kandang, pupuk hijau, dan pupuk organik.

e. Pemberantasan hama dan penyakit dengan pestisida.

f. Panen tepat waktu, artinya tidak terlalu awal dan terlambat sehingga akan memberikan hasil yang maksimal.

g. Pola tanam perlu dipatuhi, terutama jarak antar tanaman dan pergantian jenis tanaman yang dapat mengurangi kegagalan panen.

Tidak ada yang lebih menggembirakan petani kelapa sawit selain diperolehnya produksi yang lebih tinggi pada waktu pemanenan. Mutu intensifikasi merupakan faktor yang dapat mempengaruhi produksi kelapa sawit dan akhirnya akan mempengaruhi pendapatan,

Soewardi (1996 : 22) menyatakan bahwa masyarakat desa dapat dikelompokkan atas 2 lapisan yaitu masyarakat lapisan atas yang aktif terhadap modernisasi pertanian dan masyarakat lapisan bawah yang kurang aktif terhadap modernisasi pertanian. Masyarakat lapisan atas akan melaksanakan dan menjalanakan kegiatan yang mengarah kepada peningkatan perubahan mutu yang lebih baik.

Sistem intensifikasi pengelolaan usahatani kelapa sawit meliputi beberapa jenis kegiatan yaitu : pemupukan, pemberantasan hama/penyakit tanaman dan pemanenan. Mutu intensifikasi pada usahatani kelapa sawit adalah kegiatan pemupukan, pemberantasan hama/penyakit tanaman dan pemanenan dengan meningkatkan kualitas yang lebih baik.

Selanjutnya Hanum (2008 : 444) menyatakan bahwa : Tujuan pemupukan agar tanaman kelapa sawit memproduksi buah dengan optimal, pemupukan setahun 3-4 kali atau dapat juga setiap bulan agar unsur hara tetap tersedia. Pupuk Nitrogen $(\mathrm{N})$ dapat diperoleh dari Urea $(46 \% \mathrm{~N})$ dengan dosis 100-200 gr/pokok TBM (Tanaman Belum Menghasilkan) dan 300-400 gr/pokok TM (Tanaman Menghasilkan). Posphor (P) dapat diperoleh dari TSP (46\%) dengan dosis 100-200 gr/pokok TBM dan 300-400 gr/pokok TM. Kalium (K) dapat diberikan dengan dosis 50100 gr/pokok TBM dan 200-300 gr/pokok TM.

Hama dan penyakit atau Organisme Pengganggu Tanaman (OPT) dapat menghambat pertumbuhan tanaman mulai dari akar, batang, daun hingga ke buah sehingga mengakibatkan tanaman menjadi rusak bahkan mati. OPT tersebut harus segera mungkin dibasmi untuk menghambat laju pertumbuhannya agar tidak terlalu banyak menyebar keseluruh tanaman. Kelemahan petani saat ini yaitu kurangnya pengetahuan petani tentang OPT yang menyerang tanaman mereka sehingga OPT tersebut terus merusak tanaman.

Menurut Abdul Latief (2005:3), sasaran pengendalian hama terpadu (PHT) adalah:

1. Produktivitas pertanian yang mantap dan tinggi.

2. Penghasilan dan kesejahteraan petani meningkat.

3. Populasi hama, patogen tumbuhan dan kerusakan tanaman karena serangannya tetap berada pada tingkat yang secara ekonomis tidak merugikan.

4. Pengurangan resiko pencemaran lingkungan akibat penggunaan pestisida.

Petani adalah sebagai juru tani dalam mengelola usahataninya termasuk dalam pemberantasan hama/penyakit tanaman kelapa sawit. Sistem intensifikasi yang tujuannya untuk peningkatan produksi salah satu yang dilaksanakan adalah pemberantasan hama dan penyakit yang menyerang pada tanaman kelapa 
sawit. Sasarannya bermacam-macam, seperti serangga, tikus, mamalia (terutama hama babi) atau mikrobia yang dianggap mengganggu.

Rini (2004:5), mengatakan bahwa : Pestisida sering digunakan sebagai pilihan utama untuk memberantas organisme pengganggu tanaman (OPT), karena pestisida mempunyai daya bunuh yang tinggi, penggunaannya mudah dan hasilnya cepat diketahui. Namun aplikasinya penggunaannya akan berdampak pada penggunanya, hama sasaran maupun lingkungan disekitar yang sangat berbahaya.

Pestisida adalah substansi kimia dan bahan lain serta jasad renik dan virus yang digunakan untuk mengendalikan berbagai hama. Hama adalah semua hewan atau binatang yang mengganggu tanaman sehingga meerugikan tanaman, yaitu : serangga, siput, tikus, burung, babi dan hewan lain yang dianggap merugikan. Dengan melihat besarnya kehilangan hasil yang dapat diselamatkan berkat penggunaan pestisida, maka dapat dikatakan bahwa peranan pestisida sangat besar dan merupakan sarana penting yang sangat diperlukan dalam bidang pertanian.

Selanjutnya Sutopo (2011 : 23) menjelaskan bahwa : "Secara umum, disarankan waktu yang baik untuk menyemprot pestisida adalah pagi hari (jam 07.00-10.00) dan pada sore hari (jam 15.00-18.00)". Cara penggunaan pestisida harus benar-benar sesuai dengan keadaan angin dan suhu udara. Keadaan angin yang tenang dan suhu udara yang sedang adalah cara yang tepat dalam penggunaan pestisida.

Penggunaan pestisida sering diandalkan untuk melawan jasad pengganggu. Selain pestisida tehnik pengendalian lain banyak namun tidak mudah untuk dilakukan, kadang-kadang memerlukan tenaga yang banyak, waktu dan biaya yang besar, hanya dapat dilakukan dalam kondisi tertentu yang tidak dapat diharapkan efektivitasnya. Pestisida saat ini masih berperan besar dalam menyelamatkan kehilangan hasil AGRISAMUDRA, Jurnal Penelitian Vol. 2 No. I Januari - Juni 2015 yang disebabkan oleh jasad pengganggu, oleh sebab itu petani mempunyai perilaku dalam menggunakan pestisida untuk memberantas hama dan penyakit tanaman.

Pemanenan tanaman kelapa sawit yang benar adalah dengan melakukan penunasan atau pembuangan pelepah yang tidak produktif lagi dengan memanen buah masak. Buah masak ditandai dengan adanya berondolan yang lepas dari tandan dan jatuh ke tanah.

Selanjutnya Hanum (2008: 445), menyatakan bahwa: Panen kelapa sawit yang baik adalah panen fraksi 2 dimana setiap $1 \mathrm{~kg}$ TBS terdapat 2 buah sawit yang memberondol, Fraksi 3 adalah fraksi lewat masak yang disebabkan karena terlambat panen, fraksi 1 adalah kurang masak dan fraksi 0 adalah buah mentah yang tidak boleh dipanen dan baru bisa dipanen setelah masak kemudian.

Ketentuan kriteria panen tersebut di atas menjadi dasar petani untuk dapat memanen buah kelapa sawit pada usahataninya. Petani akan menyeleksi semua buah kelapa sawit baik fraksi 3, fraksi 2, fraksi 1 maupun fraksi 0 . Kemampuan petani menyeleksi buah kelapa sawit ini merupakan mutu intensifikasi tanaman kelapa sawit.

Mutu atau kualitas merupakan ukuran baik buruknya suatu pekerjaan yang dilaksanakan. Mutu adalah nilai relatif yang ditujukan kepada sesuatu, sehingga mutu intensifikasi pertanian adalah nilai dari proses intensifikasi dalam kegiatan usahatani.

\section{METODE PENELITIAN}

Penelitian ini menggunakan "metode survei". Objek penelitian ini adalah petani yang menanam tanaman kelapa sawit di Kecamatan Sungai Raya Kabupaten Aceh Timur. Ruang lingkup penelitian ini terbatas pada pengaruh mutu intensifikasi terhadap produksi usahatani kelapa sawit di daerah penelitian. Waktu penelitian ini 
dilaksanakan pada Bulan Januari sampai dengan

Maret 2015.

Untuk menguji hipotesis digunakan Uji Regresi Linear Berganda dengan formula sebagai berikut:

$Y=a_{0}+a_{1} X_{1}+a_{2} X_{2}+a_{3} X_{3}+e$. ...(Sudjana,

2005:347)

Untuk menguji pengaruh secara serempak variabel bebas $\left(X_{1}, X_{2}\right.$ dan $\left.X_{3}\right)$ terhadap variabel terikat $(Y)$, digunakan Uji $F$ yaitu:

$F=\frac{J K_{r e g} / k}{J K_{r e s} /(n-k-1)} \ldots($ Sudjana, 2005:355)

Untuk melihat besarnya koefisien determinasi

$\left(R^{2}\right)$ digunakan rumus sebagai berikut:

$R^{2}=\frac{J K_{r e g}}{\sum y_{i}^{2}} \ldots . . .($ Sudjana, 2005:383)
Untuk mengetahui pengaruh variabel bebas terhadap variabel dependen secara parsial digunakan uji "t" dengan rumus :

$$
t=\text { Saì }^{\text {ai }}
$$

\section{E. HASIL PENELITIAN DAN PEMBAHASAN}

\section{Karakteristik Petani}

Pengertian karakteristik petani dalam penelitian ini meliputi umur petani, pendidikan, pengalaman berusahatani, tanggungan keluarga serta luas garapan yang diusahakan. Keadaan karakteristik ini dapat mempengaruhi kegiatan dan kemampuan kerja petani dalam berusahatani dalam menjalankan usahataninya, untuk lebih jelasnya mengenai keadaan karakteristik petani sampel di daerah penelitian dapat dilihat pada tabel IV-1 berikut:

Tabel IV-1. Rata-rata Karakteristik Petani Pada Usahatani Kelapa Sawit Di Daerah Penelitian.

\begin{tabular}{|l|l|c|c|c|c|}
\hline No. & \multicolumn{1}{|c|}{ Desa Sampel } & Umur (tahun) & $\begin{array}{c}\text { Pendidikan } \\
\text { (tahun) }\end{array}$ & $\begin{array}{c}\text { Pengalaman } \\
\text { (tahun) }\end{array}$ & $\begin{array}{c}\text { Tanggungan } \\
\text { (Orang) }\end{array}$ \\
\hline 1 & Buket Drien & 42,13 & 10,88 & 12,13 & 4 \\
2 & Alue Rangan & 41,15 & 10,38 & 11,15 & 4 \\
3 & Gajah Meuntah & 44,31 & 10,15 & 14,31 & 5 \\
\hline & Rata-Rata & 42,59 & 10,41 & 12,59 & 4 \\
\hline
\end{tabular}

Pada tabel tersebut di atas dapat dilihat bahwa rata-rata umur petani kelapa sawit adalah 42,59 tahun, dengan masa pendidikan 10,41 tahun, pengalaman berusahatani 12,59 tahun dan besarnya tanggungan keluarga rata-rata 4 orang.
Luas lahan garapan petani yang dimaksud dalam penelitian ini adalah luas lahan yang dikelola petani dengan tanaman kelapa sawit di daerah penelitian. Rata-rata luas garapan yang diusahakan oleh petani sampel di daerah penelitian dapat dilihat pada tabel berikut ini

\section{Luas Lahan Garapan.}

Tabel IV-2. Rata-Rata Luas Lahan Garapan Usahatani Kelapa Sawit Di Daerah Penelitian.

\begin{tabular}{|c|l|c|}
\hline No. & \multicolumn{1}{|c|}{ Desa Sampel } & Luas Garapan (Ha) \\
\hline 1 & Buket Drien & 2,13 \\
2 & Alue Rangan & 2,05 \\
3 & Gajah Meuntah & 2,14 \\
\hline & Rata-rata & 2,10 \\
\hline
\end{tabular}

Sumber: Data Primer diolah 
Dari tabel di atas terlihat bahwa rata-rata luas lahan garapan Desa Buket Drien adalah 2,13 Ha, Desa Alue Rangan 2,05 Ha dan Desa Gajah Meuntah 2,14 Ha. Sedangkan rata-rata luas garapan petani kelapa sawit di daerah penelitian adalah 2,10 $\mathrm{Ha}$.

\section{Mutu Pemupukan}

Mutu pemupukan pada usahatan kelapa sawit di daerah penelitian dinyatakan dalam Skor. Unsurunsur yang dipakai pada penentuan tingkat mutu pemupukan dalam penelitian ini terdiri dari 3 (tiga) unsur yaitu : jenis pupuk, dosis pupuk dan frekuensi pemupukan pada tanaman kelapa sawit.

Dari hasil penelitian dapat dilihat bahwa nilai rata-rata skor mutu pemupukan pada usahatani kelapa sawit Desa Buket Drien 2,71 skor, Desa Alue Rangan 2,82 skor dan Desa Gajah Meuntah 2,59 skor. Rata-rata skor mutu pemupukan pada usahatani kelapa sawit di daerah penelitian adalah 2,66 skor. Skor rata-rata mutu pemupukan ini menunjukkan angka yang sangat baik, karena nilai 2,66 skor sudah mencapai lebih dari 2,50 mendekati skor 3,00 sebagai skor tertinggi. Dalam hal ini petani di Kecamatan Sungai Raya sudah melaksanakan usahataninya dengan baik dalam hal pemupukan, sehingga mutu pemupukan sudah sesuai dengan mutu intensifikasi pertanian.

\section{Mutu Pengendalian Hama/Penyakit}

Mutu pengendalian hama/penyakit pada usahatan kelapa sawit di daerah penelitian juga dinyatakan dalam Skor. Unsur-unsur yang dipakai pada penentuan tingkat mutu pengendalian hama/penyakit dalam penelitian ini terdiri dari 3 (tiga) unsur yaitu : frekuensi pengendalian hama/penyakit, waktu pengendalian hama/penyakit dan cara pengendalian hama/penyakit pada tanaman kelapa sawit.

Dari hasil penelitian dapat dilihat bahwa nilai rata-rata skor mutu pengendalian hama/penyakit pada usahatani kelapa sawit Desa Buket Drien
2,54 skor, Desa Alue Rangan 2,67 skor dan Desa Gajah Meuntah 2,51 skor. Rata-rata mutu pengendalian hama/penyakit pada usahatani kelapa sawit di daerah penelitian adalah 2,58 skor. Skor rata-rata skor mutu pengendalian hama/penyakit ini menunjukkan angka yang sangat baik, karena skor 2,58 sudah di atas skor 2,50 . Kenyataan di lapangan juga tidak terdapat tanaman kelapa sawit yang terserang hama/penyakit.

\section{Mutu Pemanenan}

Mutu pemanenan pada usahatan kelapa sawit di daerah penelitian juga dinyatakan dalam Skor. Unsur-unsur yang dipakai pada penentuan tingkat mutu pemanenan dalam penelitian ini terdiri dari 3 (tiga) unsur yaitu : kematangan buah, waktu pemanenan dan pengambilan berondolan buah kelapa sawit.

Dari hasil penelitian dapat dilihat bahwa nilai rata-rata skor mutu pemanenan pada usahatani kelapa sawit Desa Buket Drien 2,79 skor, Desa Alue Rangan 2,82 skor dan Desa Gajah Meuntah 2,74 skor. Rata-rata skor mutu pemanenan pada usahatani kelapa sawit di daerah penelitian adalah 2,78 skor. Skor rata-rata mutu pemanenan ini menunjukkan angka yang sangat baik, karena skor 2,78 melebihi skor 2,50 mendekati skor 3,00 sebagai skor tertinggi.

\section{Produksi}

Produksi adalah hasil fisik kelapa sawit setelah di panen petani dalam bentuk Tandan Buah Segar (TBS) dan dalam bentuk berondolan buah kelapa sawit. Produksi kelapa sawit petani sampel dapat dilihat pada tabel berikut :

Tabel IV-6. Produksi Usahatani Kelapa Sawit Petani Sampel di Daerah Penelitian, 2014.

\begin{tabular}{|c|l|c|}
\hline No. & \multicolumn{1}{|c|}{ Desa Sampel } & $\begin{array}{c}\text { Produksi } \\
(\mathrm{Kg})\end{array}$ \\
\hline 1 & Buket Drien & $18.540,98$ \\
2 & Alue Rangan & $17.997,65$ \\
3 & Gajah Meuntah & $18.664,35$ \\
\hline & Rata-rata & $8.752,58$ \\
\hline
\end{tabular}


Dari tabel di atas dapat dilihat bahwa rata-rata produksi pada usahatani kelapa sawit Desa Buket Drien 18.540,98 kg, Desa Alue Rangan 17.997,65 kg dan Desa Gajah Meuntah 18.664,35 Kg. Ratarata produksi pada usahatani kelapa sawit di daerah penelitian $18.380,41 \mathrm{Kg} / \mathrm{UT}$ atau $8.752,58$ $\mathrm{Kg} / \mathrm{Ha}$.

\section{Pengaruh Mutu Intensifikasi Terhadap Produksi}

Intensifikasi tanaman kelapa sawit adalah usaha peningkatan produksi kelapa sawit tanpa menambah luas areal tanam. Intensifikasi yang dianalisis pada penelitian ini adalah mutu intensifikasi pada usahatani kelapa sawit tersebut. Mutu intensifikasi meliputi mutu pemupukan, mutu pengendalian hama/penyakit dan mutu pemanenan. Mutu intensifikasi di daerah penelitian mempengaruhi produksi pada usahatani kelapa sawit. Untuk mengetahui besarnya pengaruh tersebut, maka dianalisis dengan menggunakan regresi linier berganda dengan tiga variabel bebas sehingga diperoleh persamaan sebagai berikut: $Y=5,935+0,507 X_{1}+0,489 X_{2}+0,073 X_{3}$.

Artinya jika mutu pengendalian hama/penyakit dan mutu pemanenan dianggap tetap maka setiap penambahan mutu pemupukan 1 skor akan menyebabkan penambahan produksi 507 kg. Hal ini terjadi karena dengan mutu pemupukan meningkat maka produksi juga meningkat, karena tanaman cukup unsur hara. Jika mutu pem upukan dan mutu pemanenan dianggap tetap maka setiap penambahan mutu pengendalian hama/penyakit 1 skor akan menyebabkan penambahan produksi $489 \mathrm{~kg}$. Hal ini terjadi karena dengan mutu pengendalian hama/penyakit meningkat maka produksi juga meningkat, karena tanaman bebas dari hama/penyakit. Jika mutu pemupukan dan mutu pengendalian hama/penyakit dianggap tetap maka setiap penambahan mutu pemanenan 1 skor akan menyebabkan penambahan produksi $73 \mathrm{~kg}$. Hal ini terjadi karena dengan mutu pemanenan meningkat maka produksi juga meningkat, karena dengan panen yang benar maka tidak terbuang produksi yang ada.

Kemudian untuk melihat variasi naik turunnya produksi (Y) terhadap mutu pemupukan $\left(\mathrm{X}_{1}\right)$, mutu pengendalian hama/penyakit $\left(X_{2}\right)$ dan mutu pemanenan $\left(X_{3}\right)$ dianalisis dengan menghitung nilai koefisien determinasi $\left(R^{2}\right)$. Dari hasil perhitungan koefisien determinasi menunjukkan bahwa besarnya $\mathrm{R}^{2}=0,887$. Ini berarti variasi terhadap naik turunnya produksi $(\mathrm{Y})$ dipengaruhi oleh mutu pemupukan $\left(X_{1}\right)$, mutu pengendalian hama/penyakit $\left(X_{2}\right)$ dan mutu pemanenan $\left(X_{3}\right)$ sebesar $88,7 \%$ dan sisanya $11,3 \%$ lagi dipengaruhi oleh faktor lain yang tidak ikut diteliti dalam penelitian ini. Hasil pengujian secara serempak dapat dilihat bahwa $\mathrm{F}$ cari $=$ $78,50>\mathrm{F}$ tabel $=2,92$ pada tingkat kepercayaan 95\% $(\alpha=0,05)$ dan F tabel $=4,51$ pada tingkat kepercayaan 99\% $(\alpha=0,01)$, sehingga dapat dikatakan bahwa mutu pemupukan, mutu pengendalian hama/penyakit dan mutu pemanenan secara serempak berpengaruh sangat nyata terhadap produksi pada usahatani kelapa sawit di Kecamatan Sungai Raya Kabupaten Aceh Timur. Hal ini karena mutu pemupukan, mutu pengendalian hama/penyakit dan mutu pemanenan yang merupakan unsurunsur dari mutu intensifikasi yang harus dilaksanakan karena ketiga unsur tersebut mempengaruhi produksi kelapa sawit.

Untuk mengetahui besarnya pengaruh mutu pemupukan $\left(\mathrm{X}_{1}\right)$, mutu pengendalian hama/penyakit $\left(X_{2}\right)$ dan mutu pemanenan $\left(X_{3}\right)$, terhadap produksi $(Y)$ secara parsial diuji dengan menggunakan uji t, pada tingkat kepercayaan $95 \%$ $(\alpha=0,05)$ dan $99 \%(\alpha=0,01)$ dengan $\mathrm{db}=(n-k-$ 1) $=34-3-1=30$.

Hasil pengujian secara parsial untuk mutu pemupukan dapat dilihat bahwa $\mathrm{t}_{1}$ cari $=6,1084$ 
$>\mathrm{t}$ tabel $=1,6973$ pada tingkat kepercayaan 95\% $(\alpha=0,05)$ dan $\mathrm{t}$ tabel $=2,4573$ pada tingkat kepercayaan 99\% $(\alpha=0,01)$, sehingga mutu pemupukan secara parsial berpengaruh sangat nyata terhadap produksi pada usahatani kelapa sawit di Kecamatan Sungai Raya Kabupaten Aceh Timur. Hal ini terjadi karena dengan pemupukan maka meningkatkan unsur hara di dalam tanah sehingga tanaman kelapa sawit akan meningkat produksinya. Sebaliknya tanpa pemupukan tanaman kelapa sawit akan kekurangan unsur hara dan produksi akan turun.

Hasil pengujian secara parsial untuk mutu pengendalian hama/penyakit dapat dilihat bahwa $\mathrm{t}_{2}$ cari $=5,9634>\mathrm{t}$ tabel $=1,6973$ pada tingkat kepercayaan 95\% $(\alpha=0,05)$ dan $\mathrm{t}$ tabel $=$ 2,4573 pada tingkat kepercayaan $99 \%(\alpha=0,01)$, sehingga mutu pengendalian hama/penyakit secara parsial berpengaruh sangat nyata terhadap produksi pada usahatani kelapa sawit di Kecamatan Sungai Raya Kabupaten Aceh Timur. Hal ini karena dengan pengendalian hama/penyakit akan mengakibatkan tanaman selapa sawit bebas hama/penyakit sehingga produksi meningkat.

Hasil pengujian secara parsial untuk mutu pemanenan dapat dilihat bahwa $t_{3}$ cari $=1,0282$ $<\mathrm{t}$ tabel $=1,6973$ pada tingkat kepercayaan 95\% $(\alpha=0,05)$ dan $\mathrm{t}$ tabel $=2,4573$ pada tingkat kepercayaan 99\% $(\alpha=0,01)$, sehingga mutu pemanenan secara parsial tidak perpengaruh terhadap produksi pada usahatani kelapa sawit di Kecamatan Sungai Raya Kabupaten Aceh Timur. Hal ini karena pemanenan secara fisiologis tanaman kelapa sawit tidak mempengaruhi produksi secara nyata, beda dengan pemupukan dan pengendalian hama/penyakit. Pemanenan hanya proses pengambilan hasil saja dari buah kelapa sawit (TBS) yang sudah terbentuk dari proses fisiologis tanaman kelapa sawit.

\section{F. KESIMPULAN}

a. Rata-rata umur petani kelapa sawit di daerah penelitian adalah 42,59 tahun, dengan masa pendidikan 10,41 tahun, pengalaman berusahatani 12,59 tahun dan besarnya tanggungan keluarga rata-rata 4 orang.

b. Rata-rata luas lahan garapan Desa Buket Drien adalah 2,13 $\mathrm{Ha}$, Desa Alue Rangan 2,05 $\mathrm{Ha}$ dan Desa Gajah Meuntah 2,14 Ha, sedangkan rata-rata luas garapan petani kelapa sawit di daerah penelitian adalah 2,10 Ha.

c. Rata-rata skor mutu pemupukan pada usahatani kelapa sawit di daerah penelitian adalah 2,66 skor, rata-rata skor mutu pengendalian hama/penyakit 2,58 skor dan rata-rata skor mutu pemanenan 2,78 skor, rata-rata skor mutu pemupukan, mutu pengendalian hama/penyakit dan mutu pemanenan menunjukkan nilai skor yang sangat tinggi.

d. Rata-rata produksi pada usahatani kelapa sawit Desa Buket Drien 18.540,98 kg, Desa Alue Rangan 17.997,65 kg dan Desa Gajah Meuntah 18.664,35 Kg. Rata-rata produksi pada usahatani kelapa sawit di daerah penelitian 18.380,41 Kg/UT atau 8.752,58 $\mathrm{Kg} / \mathrm{Ha}$.

e. Hasil diperoleh persamaan sebagai berikut:

$Y=5,935+0,507 X_{1}+0,489 X_{2}+0,073 X_{3}$

f. Hasil perhitungan koefisien determinasi menunjukkan bahwa besarnya $\mathrm{R}^{2}=0,887$. Ini berarti variasi terhadap naik turunnya produksi (Y) dipengaruhi oleh mutu pemupukan $\left(X_{1}\right)$, mutu pengendalian hama/penyakit $\left(\mathrm{X}_{2}\right)$ dan mutu pemanenan $\left(X_{3}\right)$ sebesar 88,7 \% dan sisanya $11,3 \%$ lagi dipengaruhi oleh faktor lain yang tidak ikut diteliti dalam penelitian ini.

g. Hasil pengujian secara serempak dapat dilihat bahwa $\mathrm{F}$ cari $=78,50>\mathrm{F}$ tabel pada tingkat 
kepercayaan $95 \%=2,92$ dan $99 \%=4,51$, sehingga mutu pemupukan, mutu pengendalian hama/penyakit dan mutu pemanenan secara serempak berpengaruh sangat nyata terhadap produksi.

h. Hasil pengujian secara parsial mutu pemupukan dapat dilihat bahwa $\mathrm{t}_{1}$ cari $=$ $6,1084>\mathrm{t}$ tabel pada tingkat kepercayaan 95\%=1,6973 dan 99\%=2,4573 sehingga mutu pemupukan secara parsial berpengaruh sangat nyata terhadap produksi. Hasil pengujian secara parsial mutu pengendalian hama/penyakit dapat dilihat bahwa $\mathrm{t}_{2}$ cari $=$ $5,9634>t$ tabel $95 \%=1,6973$ dan $99 \%=2,4573$, sehingga mutu pengendalian hama/penyakit secara parsial berpengaruh sangat nyata terhadap produksi. Hasil pengujian secara parsial untuk mutu pemanenan dapat dilihat bahwa $t_{3}$ cari = $1,0282<\mathrm{t}$ tabel pada tingkat kepercayaan $95 \%=1,6973$ dan 99\%=2,4573, sehingga mutu pemanenan secara parsial tidak berpengaruh terhadap produksi.

\section{G. DAFTAR PUSTAKA}

Abdul Latief, 2005. Permasalahan Dalam Penerapan Sistem Pengendalian Hama Terpadu Untuk Pengelolaan Penyakit Tumbuhan di Indonesia, Fakultas Pertanian Universitas Brawijaya

Aceh Timur Dalam Angka 2013. Laporan Perkebunan Rakyat, BPS Kabupaten Aceh Timur, Idi.

Ance Gunarsih K, 2004. Klimatologi, Pengaruh Iklim Terhadap Tanah dan Temperatur, Bina Aksara, Jakarta.

BPK Kecamatan Sungai Raya, 2013. Laporan Perkebunan Rakyat, Kecamatan Sungai Raya. Darianto, 2007. Sistem Intensifikasi Pertanian, Warta Pertanian Institut Pertanian Bogor (IPB), Bogor.

Dwi Astuti, 2013. Analisis Regresi Linear dan Berganda. Makalah Statistika, FE-Univ. Diponegoro, Semarang.
Hanum, 2008. Teknik Budidaya Tanaman, Jilid 3, Departemen Pendidikan Nasional, Jakarta.

Kiswanto, 2008. Teknologi Budidaya Kelapa Sawit, Badan Penelitian dan Pengembangan Teknologi Pertanian, Lampung.

Nazir, 2005. Metode Penelitian, Ghalia Indonesia, Jakarta.

Rini W, 2004. Petunjuk Penggunaan Pestisida, Penebar Swadaya, Jakarta.

Rismawan, 2010. Budidaya dan Pengelolaan Kebun Kelapa Sawit, Penebar Swadaya, Jakarta.

Soewardi H, 1996. Respon Masyarakat Desa Terhadap Modernisasi Produksi Pertanian, Fakultas Pertanian Universitas Padjajaran.

Sudjana, 2005. Metode Statistik, CV. Tarsito, Bandung.

Sugito, 1993. Kelapa Sawit, Penebar Swadaya, Jakarta.

Sutopo, 2011. Pestisida dan Perlindungan Tanaman, Warta Pertanian, Institut Pertanian Bogor - Bogor.

Su'ud, 1996. Mengenal Pembangunan Pertanian dan Perkaitannya, Universitas Syiah Kuala, Darussalam-Banda Aceh.

Sunarko, 2008. Petunjuk Praktis Budidaya dan Pengelolaan Kelapa Sawit, Agromedia Pustaka, Jakarta.

Wayan Artha, 2008. Pola Intensifikasi Peningkatan Produksi Pertanian, Buletin Pertanian, Jakarta 